\title{
Sexual maturity in western Atlantic bluefin tuna
}

SUBJECT AREAS:

ICHTHYOLOGY

REPRODUCTIVE BIOLOGY

Received

24 April 2014

Accepted

7 November 2014

Published

28 November 2014

Correspondence and requests for materials should be addressed to M.E.L. (mlutcavage@ eco.umass.edu)

\author{
Gilad Heinisch ${ }^{1,2}$, Hanna Rosenfeld ${ }^{3}$, Jessica M. Knapp ${ }^{1,2}$, Hillel Gordin ${ }^{3}$ \& Molly E. Lutcavage
}

'Large Pelagics Research Center, University of Massachusetts Amherst, Gloucester, Massachusetts 01930, USA, ${ }^{2}$ University of New Hampshire, Durham, New Hampshire 03824, USA, ${ }^{3}$ Israeli Oceanographic and Limnological Research, National Center for Mariculture, Eilat, 88112 , Israel.

We introduce a novel endocrine approach for assessing the unresolved matter of the timing of sexual maturation in western Atlantic bluefin tuna (ABFT), a highly migratory population whose status remains uncertain. Ratios of follicle stimulating hormone to luteinizing hormone, a sexual maturity indicator, in all $\mathrm{ABFT} \geq 134 \mathrm{~cm}$ curved fork length (CFL) were $<0.4$, similar to Mediterranean spawners, indicating that western ABFT mature at considerably smaller sizes and at a much younger age than currently assumed $(\geq 185 \mathrm{~cm} \mathrm{CFL})$.

T he Atlantic bluefin tuna, Thunnus thynnus (ABFT), is a long-lived, highly migratory species inhabiting the North Atlantic Ocean and adjacent seas ${ }^{1}$. Since the 1970s, the International Commission for the Conservation of Atlantic Tunas (ICCAT) has managed ABFT fisheries as eastern and western Atlantic stocks, separated by the $45^{\circ} \mathrm{W}$ meridian. This division was based on assumed separate and exclusive spawning grounds, low levels of mixing between stocks, and widely different maturity schedules. Both stocks are under constant fishing pressure and, during the last three decades, have suffered a decline in their spawning stock biomass (SSB), the total weight of all sexually mature fish in the stock².

Two major spawning basins, the Mediterranean Sea and the Gulf of Mexico/Florida Straits, are currently recognized for eastern and western $\mathrm{ABFT}$ stocks, respectively ${ }^{1,2}$. In addition, natal homing to spawning grounds has been suggested ${ }^{3,4}$. Nevertheless, there are uncertainties regarding ABFT spatial and temporal distributions, migration, stock structure, and age at sexual maturity (the age of which an individual becomes capable of reproducing sexually for the first time $e^{5}$, i.e. the first reproduction cycle). Recent studies using genetic and organochlorine tracers indicate mixing rates between the two stocks are potentially high among smaller size classes (i.e., 2-4 year-old fish) ${ }^{6,7}$, and tagging results show ABFT of various sizes crossing the $45^{\circ} \mathrm{W}$ meridian management line $e^{8-11}$. The prevailing maturation paradigm assumes differential sexual maturation schedules (age at first reproduction cycle) for eastern and western ABFT stocks ${ }^{9,12,13}$, although detailed examination of maturity ogives (the ratio of mature/immature fish at size) for the western stock is lacking. The spatial-temporal spawning behavior of ABFT across the Mediterranean Sea is well documented ${ }^{13-15}$, and the onset of sexual maturity among wild and captive Mediterranean Sea ABFT occurs in three to five year-old fish, ${ }^{13,16,17}$ usually $105-140 \mathrm{~cm}$ curved fork length (CFL). In the Gulf of Mexico/Florida Straits, maturity is assumed to be achieved in fish no younger than nine years old ${ }^{18}$. This is coincident with the minimum size for U.S. commercial landings, set at $185 \mathrm{~cm} \mathrm{CFL}$ for most sectors. The similarity in growth rates in putative eastern and western $\mathrm{ABFT}^{18}$ also raises doubt that there is a striking difference in the age of sexual maturity. Since reproduction is a major growth inhibitor in teleosts ${ }^{19}$, it is unlikely that sexual maturity, an intrinsic feature of growth and life history schedules, would vary widely ${ }^{20,21}$.

Determining accurate maturity schedules for western ABFT is necessary for precise determination of SSB, a proxy of reproductive potential ${ }^{22,23}$. A major obstacle in determining the age at median sexual maturity $\left(\mathrm{L}_{50}\right.$ or $A_{50}$ in stock assessment) is the potential for biased sampling on the spawning grounds. If non-spawners are absent from the spawning grounds, as confirmed for Mediterranean Sea ABFT ${ }^{24}$, then sampling there would identify reproductive characteristics for specific spawning locations rather than for the entire stock. Sampling only on spawning grounds can overlook alternative spawning scenarios, e.g., other locations and schedules, and possibly lead to a biased estimation of median size/age at sexual maturity ${ }^{25}$. Therefore, sampling ABFT solely in the northern Gulf of Mexico during the April-July known spawning season would provide incomplete results. Sampling on foraging grounds, where ABFT of various sizes mix, would provide additional information on the western ABFT stock reproductive behavior. For models attempting to address 
Table 1 | Morphometrics summary of Atlantic bluefin tuna by location, month and sex. Means are presented \pm SDV. GoMex- Gulf of Mexico (spawning season); GoME- Gulf of Maine; GB- Georges Bank-Northern Edge, north to the Hague line; NanS- Nantucket Sound; NS- Nova Scotia; VA-Virginia; YOY- young-of-the-year (sex could not be determined). n- number of samples; CFL- curved fork length; BW- body weight (estimated from CFL, excluding YOY of which actual BW is presented); GSI- gonado-somatic index; FSI- fat body-somatic index; NTno tissue, i.e. these fish had no fat bodies. * Data and samples were available for morphometrics only, i.e. we did not conduct endocrine analyses on these fish (five males and four females)

\begin{tabular}{|c|c|c|c|c|c|c|c|c|c|}
\hline Location & Month & Sex & $n$ & CFL range $(\mathrm{cm})$ & BW range $(\mathrm{kg})$ & CFL (Av. cm) & BW (Av. kg) & GSI (Av. \%) & FSI (Av. \%) \\
\hline GoMex & May & $\begin{array}{c}\text { Males } \\
\text { Females }\end{array}$ & $\begin{array}{l}4 \\
6\end{array}$ & $\begin{array}{l}213-269 \\
221-260\end{array}$ & $\begin{array}{l}158-301 \\
184-274\end{array}$ & $\begin{array}{l}243 \pm 27.0 \\
247+150\end{array}$ & $\begin{array}{l}232 \pm 69.5 \\
241+354\end{array}$ & $\begin{array}{l}3.2 \pm 1.86 \\
37+0.80\end{array}$ & $\begin{array}{l}\text { NT } \\
\text { NT }\end{array}$ \\
\hline \multirow[t]{4}{*}{ GoME } & Jun & Males & 3 & $158-173$ & $66-86$ & $166 \pm 7.9$ & $77 \pm 10.2$ & $0.4 \pm 0.05$ & $0.4 \pm 0.18$ \\
\hline & & Females & 2 & $155-163$ & $63-73$ & $159 \pm 5.4$ & $68 \pm 6.6$ & $0.6 \pm 0.21$ & $0.4 \pm 0.46$ \\
\hline & & Males & 9 & $185-229$ & $105-191$ & $197 \pm 13.7$ & $128 \pm 27.0$ & $0.3 \pm 0.12$ & $0.1 \pm 0.19$ \\
\hline & & Females & 3 & $189-240$ & $111-219$ & $207 \pm 28.4$ & $149 \pm 60.3$ & $0.4 \pm 0.32$ & $0.1 \pm 0.24$ \\
\hline \multirow[t]{4}{*}{ GoME } & Jul & Males & 1 & & & 170 & 82 & 1.0 & 0.5 \\
\hline & & Females & 1 & & & 157 & 66 & 0.9 & 0.4 \\
\hline & & Males & 3 & $217-279$ & $165-338$ & $248 \pm 30.9$ & $249 \pm 86.8$ & $0.5 \pm 0.37$ & $0.2 \pm 0.02$ \\
\hline & & Females & 4 & $190-226$ & $112-185$ & $202 \pm 16.4$ & $137 \pm 33.2$ & $0.6 \pm 0.14$ & $0.5 \pm 0.16$ \\
\hline \multirow[t]{2}{*}{ GoME } & Aug & Males & 6 & $145-175$ & $51-89$ & $154 \pm 14.1$ & $62 \pm 17.7$ & $0.2 \pm 0.22$ & $0.3 \pm 0.07$ \\
\hline & & Females & 5 & $135-165$ & $41-75$ & $146 \pm 11.5$ & $53 \pm 13.1$ & $0.2 \pm 0.13$ & $0.1 \pm 0.11$ \\
\hline \multirow[t]{2}{*}{ GoME + GB * } & Aug & Males & 5 & $239-269$ & $226-320$ & $255 \pm 13.4$ & $274 \pm 42.5$ & $0.5 \pm 0.32$ & $0.2 \pm 0.28$ \\
\hline & & Females & 7 & $189-257$ & $113-280$ & $219 \pm 24.6$ & $180 \pm 60.6$ & $0.5 \pm 0.15$ & $0.3 \pm 0.23$ \\
\hline \multirow[t]{2}{*}{ GoME + NanS } & Sep & Males & 7 & $135-165$ & $42-78$ & $151 \pm 10.2$ & $61 \pm 12.3$ & $0.1 \pm 0.05$ & $0.2 \pm 0.09$ \\
\hline & & Females & 13 & $138-166$ & $45-80$ & $152 \pm 9.8$ & $61 \pm 11.9$ & $0.2 \pm 0.17$ & $0.3 \pm 0.18$ \\
\hline \multirow[t]{2}{*}{ NS } & Sep & Males & 2 & $264-269$ & $327-347$ & $267 \pm 3.6$ & $337 \pm 14.0$ & $0.3 \pm 0.08$ & $0.3 \pm 0.11$ \\
\hline & & Females & 3 & $234-249$ & $226-273$ & $241 \pm 7.6$ & $249 \pm 23.5$ & $0.4 \pm 0.06$ & $0.7 \pm 0.70$ \\
\hline \multirow[t]{2}{*}{ NS } & Oct & Males & 5 & $221-279$ & $199-433$ & $253 \pm 26.4$ & $322 \pm 104.9$ & $0.2 \pm 0.05$ & $0.7 \pm 0.16$ \\
\hline & & Females & 4 & $221-292$ & 199-501 & $264 \pm 30.4$ & $374 \pm 126.5$ & $0.3 \pm 0.04$ & $0.5 \pm 0.12$ \\
\hline VA (YOY) & Sep & & 17 & $26-37$ & $0.24-0.92$ & $31 \pm 3.1$ & $0.5 \pm 0.20$ & $0.0 \pm 0.00$ & NT \\
\hline
\end{tabular}

sexual maturity in fish outside the spawning season, a new challenge emerges: identifying accurate physiological indicators for assessing ABFT sexual maturity during the non-reproductive season.

ABFT are iteroparous (have multiple reproductive cycles) batch spawners. Mature individuals are assumed to spawn every year over a period of weeks in warm temperate seas. Since ABFT have high metabolic rates, vitellogenic oocytes, hydrated oocytes and post-ovulatory follicles (i.e., signs of maturity) are absorbed soon after reproduction ceases ${ }^{26}$. Although in some cases maturity status was determined from histological investigation in fish during the non-spawning season ${ }^{27,28}$, distinguishing resting-inactive ovaries in sexually mature fish from ovaries of immature fish remains difficul $^{29}$. Endocrine profiling, however, provides alternative, direct, and accurate information on sexual maturation. In teleosts, the brain-pituitary-gonad (BPG) axis is activated during sexual maturation $^{30}$. Two of its key modulators, the gonadotropins (GtHs) follicle stimulating hormone (FSH) and luteinizing hormone (LH), are synthesized and secreted by the pituitary gland under hypothalamic regulation. The relative dominance of FSH over LH prior to sexual maturation has been demonstrated in several teleosts ${ }^{5,31}$, including striped bass, Morone saxatilis ${ }^{32}$, yellowtail flounder, Limanda ferruginea ${ }^{33}$, European seabass, Dicentrarchus labrax ${ }^{34}$, platyfish, Xiphophorus maculatus ${ }^{35}$ and salmonids, Oncorhynchus spp. ${ }^{36}$. FSH/LH levels and ratios have been measured in mature and immature captive $\mathrm{ABFT}^{37}$. In the latter, a FSH/LH ratio greater than 1.0 was confirmed and comparable to mammals ${ }^{38,39}$. These recent findings support new approaches for investigating ABFT sexual maturity in the wild via the monitoring of pituitary gonadotropins.

In an effort to better understand ABFT sexual maturity schedules and to investigate the perceived physiological differences in sexual maturation among putative eastern and western ABFT, we analyzed the reproductive status and the pituitary gonadotropins levels in ABFT of various sizes sampled during the non-spawning season on NW Atlantic foraging grounds.

\section{Results}

Morphometrics. ABFT sampled were between 134-292 cm CFL, with the exception of the Age 0's, known as young of the year (YOYs; $<40 \mathrm{~cm} \mathrm{CFL),} \mathrm{and} \mathrm{assigned} \mathrm{to} \mathrm{two} \mathrm{size} \mathrm{groups,} \mathrm{134-}$ $185 \mathrm{~cm}$ CFL - presumably immature, and $\geq 185 \mathrm{~cm} \mathrm{CFL} \mathrm{-} \mathrm{mature}$ (Table 1). Fish sampled off Nova Scotia were all $\geq 185 \mathrm{~cm}$ CFL and were all sampled in October 2009 and September 2010. YOY bluefin tuna (CFL; $31 \pm 3.1,486 \pm 188.3 \mathrm{~g}$, were all sampled on 13 September, 2008 off Virginia. YOY bluefin tuna were caught while schooling with YOY blackfin tuna (Thunnus atlanticus), skipjack tuna (Katsuwonus pelamis), little tunny (Euthynnus alletteratus), and young dolphin fish (Coryphaena hippurus).

ABFT gonad and perigonadal fat body indices (i.e. GSI and FSI) within each sampling region did not differ significantly between sexes or among sizes and were grouped together for statistical analyses. Mean GSI was significantly higher $(p<0.05)$ in fish sampled in the Gulf of Mexico $(3.5 \pm 1.26)$ than in fish sampled on foraging grounds $(\leq 1.0)$ (Fig. 1). All gonads sampled in the NW Atlantic foraging grounds weighed $50-2100 \mathrm{~g}$ and were in a non-reproduction condition (as indicated by gonad weight and histology/oocyte morphology- e.g. lack of hydrated oocytes and post ovulatory follicles). Mean perigonadal fat body indices (FSI) were high in July ( 0.5 $\pm 0.23)$, decreased in August $(0.2 \pm 0.20)$, and then increased in October $(0.6 \pm 0.16)$. May fish (sampled in the Gulf of Mexico) had no perigonadal fat. In YOY the gonads were thin, almost unnoticeable, and with no detectable perigonadal fat.

Gonad Histology. The majority of oocytes from females $(\geq 134 \mathrm{~cm}$ CFL) sampled in the NW Atlantic were in the perinucleolar stage (i.e. primary growth), with no visual difference observed between females of different sizes. Lipid stage oocytes (also termed cortical alveolar ${ }^{27}$ ) were also present in females across the entire size range (Fig. 2). All testes were partially spent (Fig. 3). Milt was present in testes of males of all sizes during June-August. In one case $(145 \mathrm{~cm}$ CFL male sampled on August 27, 2008), milt was flowing freely from the testis when sectioned, an indication of male sexual maturity ${ }^{40}$. 

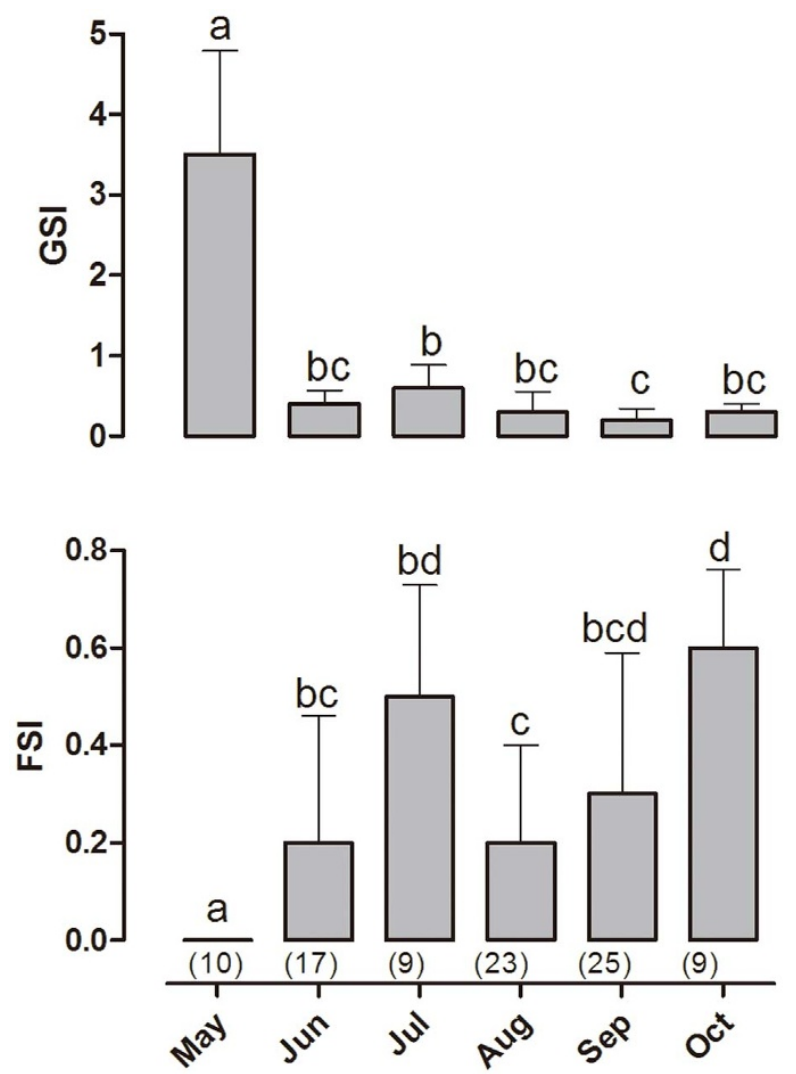

Figure $1 \mid$ Gonad and fat body somatic indices. GSI and FSI presented as mean $( \pm$ SDV). Males and females were grouped together. May fish were sampled in the Gulf of Mexico during spawning season. June-October fish were sampled on NW Atlantic foraging grounds: the Gulf of Maine, Nantucket Sound, Georges Bank and off Nova Scotia during foraging season. Normal distribution was achieved via arcsine transformation, and confirmed by Shapiro-Wilk $W$ test. Lower case letters indicate significant difference between means (Tukey-Kramer, $\alpha=0.05$ ). Sample sizes are in parentheses (n).

Pituitary GtHs Levels. We detected a significant difference $(p<$ 0.05) in the FSH/LH ratio between YOYs and ABFT larger than $134 \mathrm{~cm}$ CFL (Fig. 4). The mean ratio for the YOY was $17.1 \pm$ 17.53, with individual ratios ranging between 2.0 and 46.05 . The $\mathrm{FSH} / \mathrm{LH}$ ratio was $<0.36$ in all other fish, with a minimum ratio of 0.01 . We did not detect significant differences in the mean FSH/ LH ratios between fish $134-185 \mathrm{~cm}$ CFL vs. $\geq 185 \mathrm{~cm} \mathrm{CFL}(p<$ $0.05)$.

Mean pituitary LH levels measured in fish landed off Nova Scotia (September-October; $44 \pm 8.3 \mu \mathrm{g} / \mathrm{pit} / \mathrm{BW}$ ) were significantly lower than those of females sampled in June-August in the Gulf of Maine $(p<0.05)$. Mean pituitary LH levels of females sampled in the Gulf of Maine (June-August) were not significantly different between size classes (134-185 cm CFL vs. $\geq 185 \mathrm{~cm}$ CFL; $p<0.05$ ). No significant differences were detected in pituitary LH levels among males (Supplementary Fig. S1; Supplementary Table S1).

Mean pituitary FSH levels of fish $>134 \mathrm{~cm}$ CFL (Supplementary Fig. S2) were one order of magnitude lower than the LH levels. Significant differences in pituitary FSH were observed only in September-October where FSH (and LH) levels were higher in smaller fish compared to larger fish for both males and females $(p<0.05)$. In addition, females $\geq 185 \mathrm{~cm}$ CFL sampled during May in the Gulf of Mexico had FSH levels lower than the assay sensitivity (Supplementary Fig. S2). Mean pituitary FSH levels were significantly different among the smaller females (134-185 cm CFL), where levels increased from $6.6 \pm 0.75 \mu \mathrm{g} / \mathrm{pit} / \mathrm{BW}$ in June-August

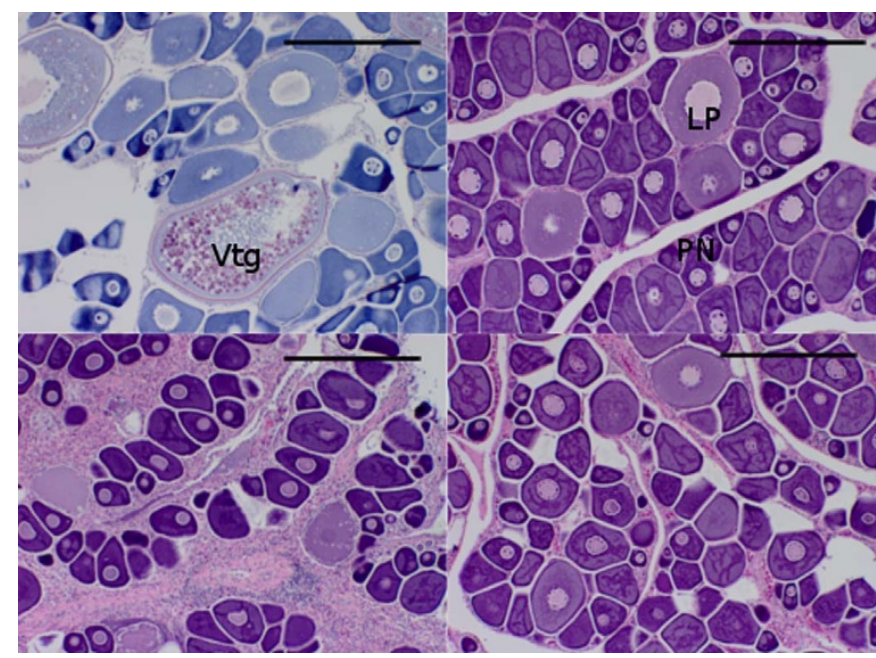

Figure $2 \mid$ Ovaries. Micrographs of ABFT ovaries sampled during JuneJuly in the NW Atlantic (top) and August-September (bottom). Top left$190 \mathrm{~cm}$ CFL; Top right- $162 \mathrm{~cm}$ CFL; Bottom left- $205 \mathrm{~cm}$ CFL; Bottom right- $156 \mathrm{~cm}$ CFL. PN - perinucleolar stage; LP - lipid stage; Vtg vitellogenic oocyte. $\mathrm{Bar}=300 \mu \mathrm{m}$.

to $17.1 \pm 7.56 \mu \mathrm{g} / \mathrm{pit} / \mathrm{BW}$ in September (all females sampled in the Gulf of Maine; $p<0.05$ ). Mean pituitary FSH levels of males did not change significantly, except the significant $(p<0.05)$ elevation in smaller males (134-185 cm CFL) during September-October.

\section{Discussion}

This study introduces a novel approach for assessing sexual maturity in ABFT via characterization of intra-pituitary GtHs levels. Using this method, we have determined that the current paradigm of widely different maturity schedules for eastern and western ABFT is incorrect. Although we did not determine natal origin in this study, previous studies suggest that western ABFT dominate the New England and Canadian Atlantic commercial fisheries in our sampling area. Otolith chemistry indicated that $\sim 95 \%$ of large ( $\geq 185 \mathrm{~cm} \mathrm{CFL}$ ) ABFT sampled in the Gulf of Maine were of western origin ${ }^{4,41}$. Eastern dispersals and entries into the Mediterranean Sea are rare among ABFT tagged in the NW Atlantic ${ }^{11,42}$. In addition, biomarker studies indicated western origins for $\mathrm{YOY}^{6}$ that do not transit the

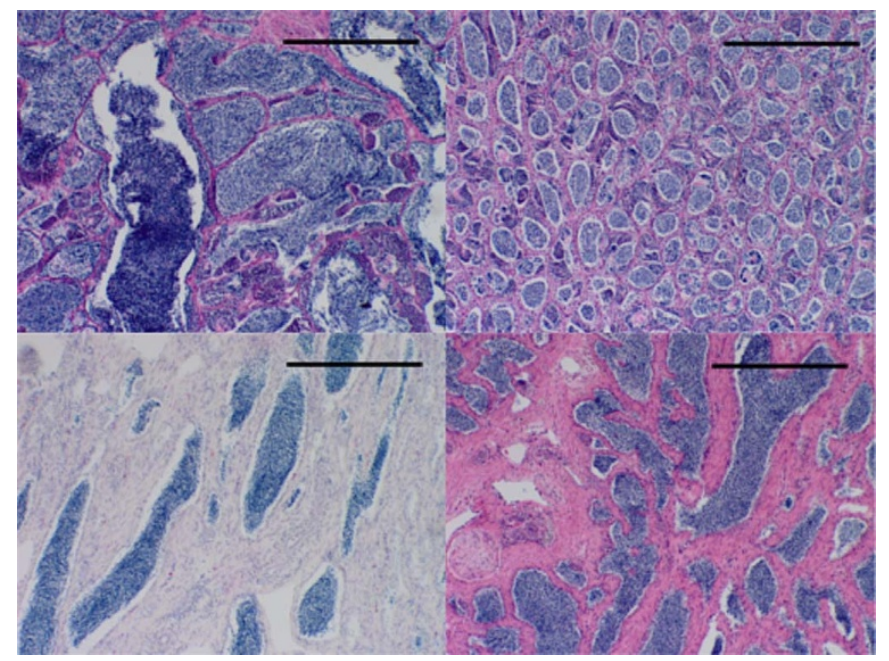

Figure 3 Testes. Micrographs of ABFT testes sampled during June (top) and August (bottom) in the NW Atlantic. Top left- $229 \mathrm{~cm}$ CFL; Top right- 157 cm CFL; Bottom left- 145 cm CFL; Bottom right- 169 cm CFL. Bar $=300 \mu \mathrm{m}$. 


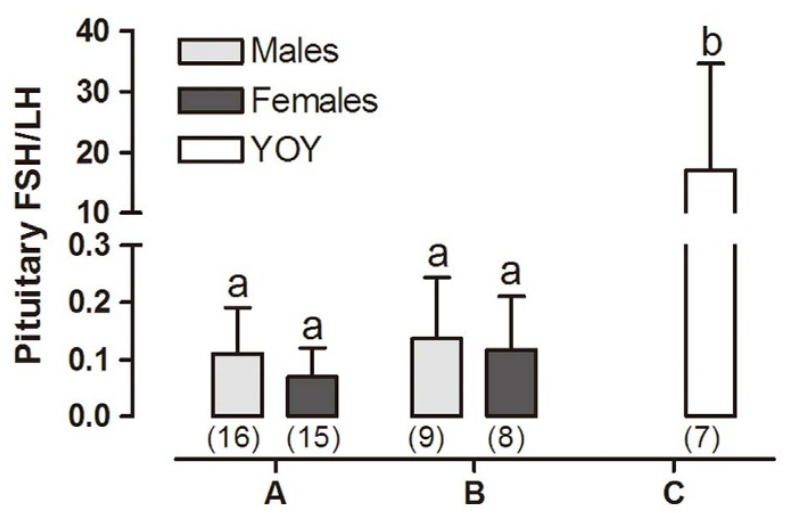

Figure $4 \mid$ Mean FSH/LH ratios. Protein FSH levels ( $\mu \mathrm{g} / \mathrm{pit} / \mathrm{BW}$ ) divided by protein LH levels ( $\mu \mathrm{g} / \mathrm{pit} / \mathrm{BW}$ ) for each individual and then averaged for comparison. On the $\mathrm{X}$ axis are the fish grouped by size: $\mathrm{A} \geq 185$; B 134-185; $\mathrm{C} \leq 37$ (CFL length in $\mathrm{cm}$ ). All fish, males and females $>134 \mathrm{~cm}$ CFL had FSH/LH protein ratios $<0.36$ (average: $0.1 \pm 0.08$ ). All YOY ABFT $(\leq 37 \mathrm{~cm})$ were sampled on 13 September 2008 off Virginia, USA. FSH/LH ratio for YOYs ranged between 2.00 and 46.05. For statistical comparison data were normalized using arcsine transformation, and confirmed by Shapiro-Wilk $W$ test. Letters above error bars (SDV) indicate significant difference between means (Tukey-Kramer, $\alpha=0.05$ ), Numbers of samples (n).

Atlantic until they are 1-2 year-old ${ }^{1}$. Although it is possible that some smaller, older (134-185 cm CFL) individuals were of eastern origin ${ }^{4}$, it is highly unlikely that our entire sample was comprised of eastern origin fish.

Mean GSI levels of the fish sampled in the northern Gulf of Mexico during May (Fig. 1), the height of the known spawning season, are similar to previously reported GSI values for ABFT and are characteristic of Mediterranean ABFT during the spawning season ${ }^{14,15}$. Mean pituitary LH levels (Supplementary Fig. S1) are similar to ABFT sampled in the Mediterranean Sea ${ }^{17,37}$ and are an order of magnitude higher than those of pituitary FSH (Supplementary Fig. S2). This supports differential synthesis and accumulation kinetics for pituitary $\mathrm{LH}$ and $\mathrm{FSH}^{32,37,43,44}$. The high pituitary $\mathrm{LH}$ levels recorded in this study are typical of ABFT and may compensate for high volume dilution after being secreted into the blood circulation of such a large fish ${ }^{17}$. Following secretion, ABFT LH levels are similar to circulating LH levels measured in striped bass and sea breams ${ }^{45,46}$.

We did not detect significant differences in mean pituitary LH between ABFT $\geq 185 \mathrm{~cm}$ CFL (mature) vs. 134-185 cm CFL ABFT (currently assumed immature). Such differences were recorded in striped bass ${ }^{45}$ where pituitary LH levels were highest in mature individuals, intermediate in fish at puberty, and lowest among juveniles. The lack of difference in pituitary LH levels among ABFT of different size classes indicates these fish share a similar physiological maturity status, i.e., $\mathrm{ABFT} \geq 134 \mathrm{~cm}$ CFL are mature. We also compared pituitary FSH/LH ratios between YOY (immature) sampled off Virginia, USA, and the fish sampled in the NW Atlantic foraging grounds (Fig. 4). Since FSH is the dominant GtH in immature fish ${ }^{5}$, immature individuals should have $\mathrm{FSH} / \mathrm{LH}$ ratio higher than 1.0, as demonstrated in ABFT sampled in the Mediterranean $\mathrm{Sea}^{37}$. Indeed, all YOY analyzed had GtHs ratios $>2.0$. Larger, presumably mature fish ( $\geq 185 \mathrm{~cm} \mathrm{CFL),} \mathrm{had,} \mathrm{as}$ expected, GtHs ratios $<0.3$. Similarly, the GtHs ratios of all fish from 134-185 cm CFL were $<0.4$, characteristic of mature fish. In the current ICCAT stock assessment for western ABFT, these size classes are considered sexually immature.

Our endocrine results demonstrate that western ABFT of sizes 134-185 cm CFL sampled in the NW Atlantic are sexually mature, and consequently, alternative reproductive behavior scenarios should be considered. Goldstein et al. ${ }^{29}$ identified three alternatives to the prevailing reproduction paradigm: natural variation, alternative spawning grounds, and skipped spawning. That study's major limitation was that only large ABFT ( $\geq 185 \mathrm{~cm}$ CFL) were analyzed. Our results include smaller individuals and confirm that alternative spawning scenarios, especially additional spawning grounds, might be realistic. Pop-up satellite archival tags (PSATs) deployed on adult ABFT in NW Atlantic foraging grounds have identified complex migration patterns $s^{3,9,10}$. More than $40 \%$ of tagged adults (173$318 \mathrm{~cm} \mathrm{CFL)} \mathrm{did} \mathrm{not} \mathrm{enter} \mathrm{either} \mathrm{documented} \mathrm{spawning} \mathrm{ground}{ }^{11}$, suggesting that alternative spawning behaviors (e.g., skipped spawning and additional spawning grounds) should be considered. A bluefin life history model based on energetic reserves predicts that smaller, younger ABFT may spawn in regions closer to foraging grounds than larger individuals and are more likely to skip spawning $^{47}$ as is found in cod and other pelagic species ${ }^{48,49}$. Some smaller western ABFT might be spawning outside of the northern Gulf of Mexico.

Our study further suggests that alternative spawning scenarios should not be limited to young spawners. Low pituitary LH levels measured during September-October in large fish $(221-292 \mathrm{~cm}$ CFL) sampled near Nova Scotia, were similar to the LH levels sampled in June in the Gulf of Maine (Supplementary Fig. S1). It is possible that these fish secreted the $\mathrm{LH}$ from the pituitary to the blood circulation, or are in the initial post-spawning stages of $\mathrm{LH}$ accumulation in the pituitary. If the latter is correct, it implies that these fish are summer spawners and may use alternative spawning grounds closer to foraging areas, as previously suggested ${ }^{1}$. This would be consistent with electronic tagging results where fish bypassed known spawning grounds before returning to northern foraging grounds the next year ${ }^{9,11}$.

Going forward, a primary question, which requires clarification of the relationship between sexual maturation and spawning, is whether mature ABFT are obligatory spawners. Skipped-spawning has been suggested for southern bluefin tuna, T. maccoyii ${ }^{25}$, where tagged fish did not conduct the expected yearly migration toward the northern tropical spawning grounds. Other species, such as Atlantic Salmon, Salmo salar, and cui-ui, Chasmistes cujus, may mature before the spawning event ${ }^{50,51}$; but since $S$. salar is a semelparous species and C. cujus is a freshwater cyprinid whose spawning behavior is influenced by drought years, they may not be good models for understanding ABFT. Records from captive Pacific Bluefin tuna in Japan, as well as Mediterranean Sea ABFT spawners, indicate that these fish mature between ages two and five and are considered to reproduce annually thereafter ${ }^{13,52}$. Reports from aquaculture operations, where the species' life history is well understood, suggest that skipped spawning is a limited phenomenon. Holland et al. ${ }^{53}$ reported that a single skipped spawning event ("dummy run") can occur in young female striped bass and is likely due to insufficient energy reserves. Skipped spawning events in wild Atlantic cod were found to be energy dependent, not limited to young mature fish and consistent with predictions made by Chapman et al. ${ }^{47}$, who modeled the relationships between energetics, reproduction, and migration for ABFT. Although the body of evidence suggests that ABFT, similar to other species $^{54}$, might experience energy dependent skipped spawning events, there is currently no evidence for a systematic, continued skipped spawning behavior supporting the prevailing paradigm of late western ABFT first reproduction cycle. The assumption that sexual maturity and reproduction are coupled in ABFT is reasonable and supported by cage-reared bluefin operations, and the tenets of iteroparous reproductive physiology.

Obtaining basic biological data and identifying the proper physiological indicators for sexual maturation are crucial for unbiased SSB evaluation, which is widely used as a proxy for reproduction success and crucial for reliable stock assessment analyses. In this study, we introduce a novel approach for the investigation of sexual maturity in 


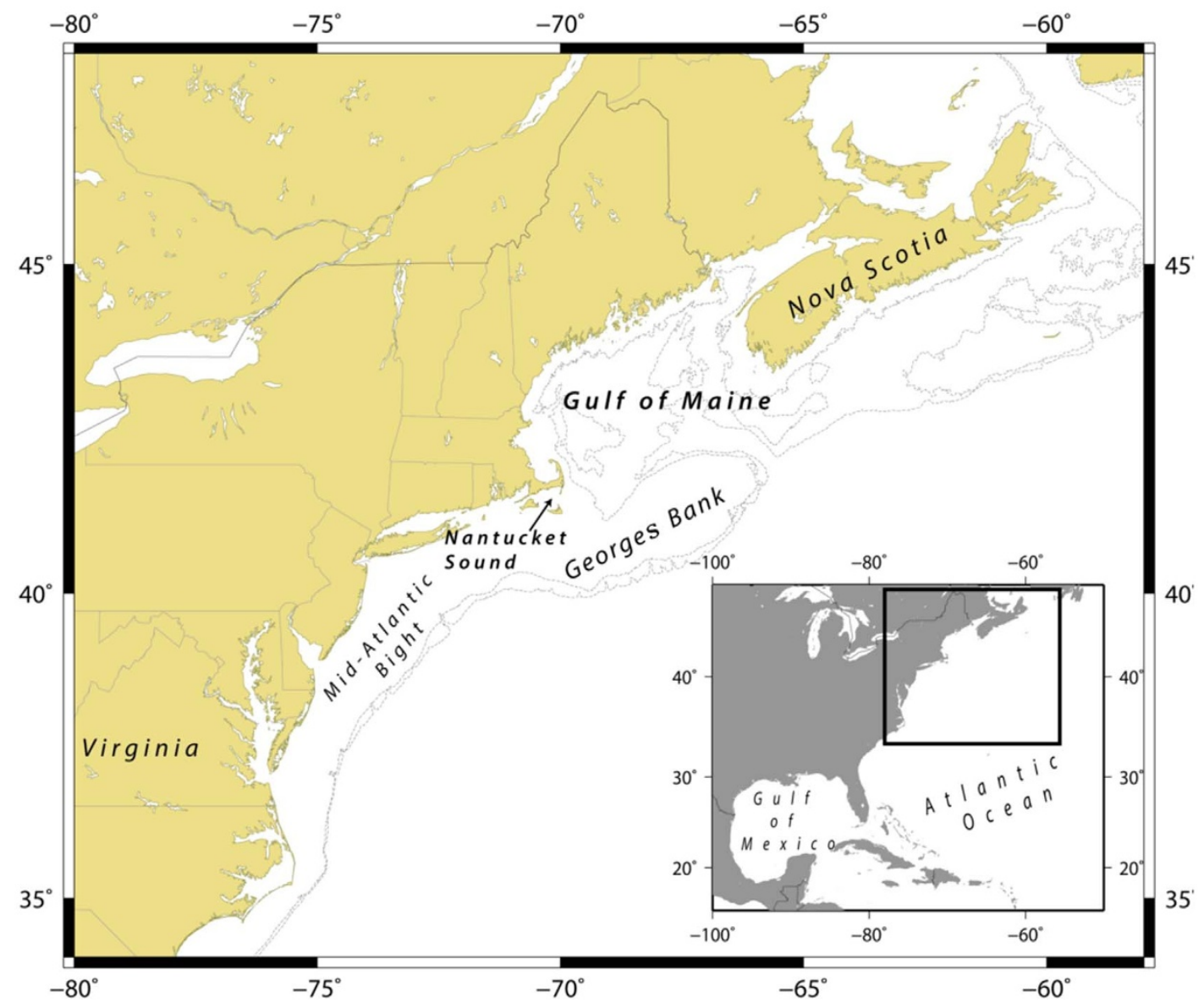

Figure 5 | The sampling grounds for Altantic bluefin tuna in the NW Atlantic. Curved fork length of sampled fish was 134-292 cm and fish were sampled on the Scotian Shelf off of Nova Scotia, Gulf of Maine, Nantucket Sound, Georges Bank, and in the Mid Atlantic Bight. Map was created using Generic Mapping Tools $(\mathrm{GMT})^{60}$.

wild stocks. The physiological mechanisms used in this study are well documented in teleosts and offer new possibilities for the determination of sexual maturity in wild fish populations.

Growing physiological and behavioral evidence call for revised maturity ogives for Western ABFT, which would contribute to more accurate stock assessments and estimates of $\mathrm{SSB}^{22}$. Studies have demonstrated similarities in trophic relationships, prey, and reproductive characteristics ${ }^{55,56}$ and the new growth curve, recently adopted for western ABFT, is nearly identical to the eastern ABFT growth curve $^{18}$. Our study suggests that the maturity ogives for eastern and western stocks may also be similar and that the current assumption of sexual maturity for western ABFT is incorrect, and may vary according to individual life history traits, as predicted by Chapman et $\mathrm{al}^{47}$. These findings have implications for ABFT management assumptions, SSB, stock assessment, and population structure, which are interrelated and influenced by maturity ogives. Therefore, a revision of the western ABFT maturity schedule is warranted.

\section{Methods}

Sampling. One hundred and ten ABFT (48 females, 45 males, and 17 YOY) were caught in the US and Canadian commercial and recreational fisheries using long-line, harpoon, or handline and were sampled during May-October, 2008-2010. Sampling was not conducted after October due to cessation of the regional fishery.

ABFT sampled in May were landed in the northern Gulf of Mexico (i.e. sampled during the reproduction season on the spawning grounds), while fish sampled during June-October were landed in Gulf of Maine, Nantucket Sound, Georges Bank and Nova Scotia (Fig. 5). YOY ABFT (assigned age $0+$ by size $\leq 37 \mathrm{~cm} \mathrm{CFL)} \mathrm{were} \mathrm{caught}$ and retained under an Exempted Fishing Permit (NMFS_TUNA-EFP-08-03) and larger individuals were sampled from federally permitted recreational $(\geq 134 \mathrm{~cm}$ $\mathrm{CFL}$ ) or commercial ( $\geq 185 \mathrm{~cm} \mathrm{CFL}$ ) landings. YOY sampled in this study had barely perceptible gonads and provided a quasi-control group for the gonadotropin ratio analysis. These fish were immature and their pituitary GtHs levels could be compared to larger, western ABFT sampled in this study, as well as to Mediterranean ABFT ${ }^{37}$.

Immediately after capture, fish were brought to the boat, killed via conventional fishing methods and sampled immediately. CFL was measured to the nearest $\mathrm{cm}$. Following decapitation, the pituitary was immediately dissected from the brain cavity, placed in dry ice or in liquid nitrogen, and later stored in liquid nitrogen and ultracold freezer $\left(-80^{\circ} \mathrm{C}\right)$ until analyses. After dissection, the mass of the gonads and perigonadal fat bodies (supplementary Fig. S3) was determined to the nearest gram (g). The somatic indices, biological markers for reproduction season, of gonads (GSI) and fat bodies (FSI) were calculated as a percent of the total body mass, which was estimated based on ICCAT fork length conversion equations ${ }^{57}$. A mid-gonad section was taken and fixed in $10 \%$ neutral buffered formalin (NBF) for histology preparation $^{56}$.

Histology. ABFT gonad sections fixed in 10\% NBF were rinsed 24 hours post sampling and the buffer was exchanged. The fixed sections were dehydrated in increasing ethanol concentrations, cleared in ClearRite ${ }^{\circledR}$ (Richard-Allan Scientific, Kalamazoo, MI), and embedded in paraffin resin. Sections were cut (5 $\mu \mathrm{m})$ and stained with haematoxylin-eosin. Oocyte stages were determined according to Corriero et al. ${ }^{26}$. Briefly, perinucleolar-stage 25-110 $\mu \mathrm{m}$; lipid-stage (also termed cortical alveolar ${ }^{27}$ ) 110-220 $\mu \mathrm{m}$; vitellogenic-stage 220-500 $\mu \mathrm{m}$; migratory nucleus stage 500-650 $\mu \mathrm{m}$; pre-hydrated-stage 650-750 $\mu \mathrm{m}$; hydrated-stage $750-900 \mu \mathrm{m}$. Testicular stages were determined according to Abascal et al. ${ }^{58}$ and Schulz et al. ${ }^{40}$.

Sample Processing. Pituitary samples were homogenized in $450 \mu \mathrm{l}$ of ultra-pure water, except for pituitaries of YOYs, which were homogenized in $250 \mu$ l of ultra-pure water due to their smaller size. For storage, $100 \mu \mathrm{l}$ of ice-cold $2 \mathrm{xPBS}(\mathrm{pH}=7.2)$ and $200 \mu \mathrm{l}$ of ice-cold 1xPBS-T were added to $100 \mu \mathrm{l}$ aliquots of the homogenate and placed in $-80^{\circ} \mathrm{C}$ until protein analyses.

Protein Quantification. $L H$ ELISA. The pituitary LH content was measured using a competitive ELISA developed for striped bass $\mathrm{LH}^{59}$ and modified for tuna species ${ }^{17}$. The sensitivity of the assay was $0.65 \mathrm{ng} / \mathrm{ml}$ and the respective inter- and intra-assay coefficients of variation were $8 \%$ and $15 \%$. 
FSH Dot Blot. Pituitary FSH levels were measured via quantitative dot blot, following the procedure described in Berkovich et al. ${ }^{37}$. Twenty $\mu$ l of each sample (diluted $1: 2$ to $1: 10)$ and $1: 2$ standard curve dilution $(2-0.0625 \mu \mathrm{g} / \mathrm{ml})$ were loaded on a nitrocellulose membrane (Whatman, Maidstone, UK). The membrane was blocked in $10 \%$ skim milk then incubated at room temperature for one hour with primary antibody ( 1 : 10,000 anti ABFT FSH). Following five washes in assay buffer (PBS-T), the membrane was incubated (room temperature, in the dark) for sixty minutes with a secondary antibody (1:5,000 GAR-HRP, Bio-Rad), followed by a second wash cycle. The membrane was then incubated for five minutes at room temperature in an ECL solution (SuperSignal, Thermo Scientific, Waltham, MA). Results were obtained and analyzed using G-Box and Gene Tools (Syngene, Cambridge, UK).

Statistical Analyses. Data were analyzed using JMP 10 Pro statistical software (SAS Institute Inc., Cary, NC). An ArcSine transformation was used to normalize GSI and FSI values. For all parameters, normal distributions were confirmed using ShapiroWilk $W$ test for Goodness of fit. One-Way ANOVA followed by Tukey-Kramer HSD $(\alpha=0.05)$ was used to determine significant differences between means. Parameters in figures and text are presented as mean \pm standard deviation (SDV).

1. Mather, F. J. I., Mason, J. M. \& Jones, A. C. Historical Document: Life history and fisheries of Atlantic bluefin tuna. U.S. Dep. Comm., NOAA Tec. Mem., NMFSSEFSC 370 (1995).

2. Fromentin, J. M. \& Powers, J. E. Atlantic bluefin tuna: population dynamics, ecology, fisheries and management. Fish Fish. 6, 281-306 (2005).

3. Boustany, A. M., Reeb, C. A. \& Block, B. A. Mitochondrial DNA and electronic tracking reveal population structure of Atlantic bluefin tuna (Thunnus thynnus). Mar. Biol. 156, 13-24 (2008).

4. Rooker, J. R. et al. Natal homing and connectivity in Atlantic bluefin tuna populations. Science 322, 742-744 (2008).

5. Taranger, G. L. et al. Control of puberty in farmed fish. Gen. Comp. Endocrinol. 165, 483-515 (2010).

6. Carlsson, J., McDowell, J. R., Carlsson, J. E. L. \& Graves, J. E. Genetic identity of YOY bluefin tuna from the eastern and western Atlantic spawning areas. J. Hered. 98, 93-98 (2007).

7. Dickhut, R. M. et al. Atlantic bluefin tuna (Thunnus thynnus) population dynamics delineated by organochlorine tracers. Env. Sci Technol 43, 8522-8527 (2009).

8. Mather, F. J. I. Transatlantic migration of two large bluefin tuna. J. Cons. Perm. Int. Explor. Mer. 27, 325-327 (1962).

9. Lutcavage, M. L., Brill, R., Skomal, G., Chase, B. \& Howey, P. Results of pop-up satellite tagging on spawning size class fish in the Gulf of Maine. Do North Atlantic bluefin tuna spawn in the Mid-Atlantic? Can. J. Fish. Aquat. Sci. 56, 173-177 (1999).

10. Block, B. A. et al. Electronic tagging and population structure of Atlantic bluefin tuna. Nature 434, 1121-7 (2005).

11. Galuardi, B. et al. Complex migration routes of Atlantic bluefin tuna (Thunnus thynnus) question current population structure paradigm. Can. J. Fish. Aquat. Sci. 67, 966-976 (2010).

12. Baglin, R. E. J. Reproductive biology of western Atlantic bluefin tuna. Fish. Bull. 80, 121-134 (1982).

13. Corriero, A. et al. Size and age at sexual maturity of female bluefin tuna (Thunnus thynnus L. 1758) from the Mediterranean Sea. J. Appl. Ichthyol. 21, 483-486 (2005).

14. Karakulak, F. S. et al. Evidence of a spawning area for bluefin tuna (Thunnus thynnus L.) in the eastern Mediterranean. J. Appl. Ichthyol. 20, 318-320 (2004).

15. Heinisch, G. et al. Spatial - temporal pattern of bluefin tuna (Thunnus thynnus L. 1758) gonad maturation across the Mediterranean Sea. Mar. Biol. 154, 623-630 (2008)

16. Mylonas, C. C. et al. Preparation and administration of gonadotropin-releasing hormone agonist (GnRHa) implants for the artificial control of reproductive maturation in captive-reared Atlantic bluefin tuna (Thunnus thynnus thynnus). Rev. Fish. Sci. 15, 183-210 (2007).

17. Rosenfeld, H. et al. GnRHa-mediated stimulation of the reproductive endocrine axis in captive Atlantic bluefin tuna, Thunnus thynnus. Gen. Comp. Endocrinol. 175, 55-64 (2012).

18. Restrepo, V. R. et al. Updated estimate of the growth curve of Western Atlantic bluefin tuna. Aquat. Living Resour. 23, 335-342 (2010).

19. Le Gac, F. et al. Growth hormone (GH) and reproduction: a review. Fish Physiol. Biochem. 11, 219-232 (1993).

20. Roff, D. A. An allocation model of growth and reproduction in fish. Can. J. Fish. Aquat. Sci. 40, 1395-1404 (1983).

21. Folkvord, A. et al. Trade-offs between growth and reproduction in wild Atlantic cod. Can. J. Fish. Aquat. Sci. 71, 1106-1112 (2014).

22. Murawski, S. A., Rago, P. J. \& Trippel, E. A. Impacts of demographic variation in spawning characteristics on reference points for fishery management. ICES J. Mar. Sci. J. Cons. 58, 1002-1014 (2001).

23. Lambert, Y. Why should we closely monitor fecundity in marine fish populations. J. Northwest. Atl. Fish. Sci. 41, 93-106 (2008).

24. Zupa, R. et al. A histological investigation of the occurrence of non-reproductive female bluefin tuna Thunnus thynnus in the Mediterranean Sea. J. Fish Biol. 75, 1221-1229 (2009).
25. Evans, K., Patterson, T. A., Reid, H. \& Harley, S. J. Reproductive schedules in Southern bluefin tuna: Are current assumptions appropriate? PLoS ONE 7, e34550 (2012)

26. Corriero, A. et al. Histological investigations on the ovarian cycle of the bluefin tuna in the western and central Mediterranean. J. Fish Biol. 63, 108-119 (2003)

27. Brown-Peterson, N. J., Wyanski, D. M., Saborido-Rey, F., Macewicz, B. J. \& Lowerre-Barbieri, S. K. A standardized terminology for describing reproductive development in fishes. Mar. Coast. Fish. 3, 52-70 (2011).

28. Farley, J. H., Williams, A. J., Hoyle, S. D., Davies, C. R. \& Nicol, S. J. Reproductive dynamics and potential annual fecundity of South Pacific albacore tuna (Thunnus alalunga). PLoS ONE 8, e60577 (2013).

29. Goldstein, J., Heppell, S., Cooper, A., Brault, S. \& Lutcavage, M. Reproductive status and body condition of Atlantic bluefin tuna in the Gulf of Maine, 20002002. Mar. Biol. 151, 2063-2075 (2007).

30. Levavi-Sivan, B., Bogerd, J., Mañanós, E. L., Gómez, A. \& Lareyre, J. J. Perspectives on fish gonadotropins and their receptors. Gen. Comp. Endocrinol. 165, 412-437 (2010).

31. Okuzawa, K. Puberty in teleosts. Fish Physiol. Biochem. 26, 31-41 (2002).

32. Hassin, S., Claire, M., Holland, H. \& Zohar, Y. Ontogeny of follicle-stimulating hormone and luteinizing hormone gene expression during pubertal development in the female striped bass, Morone saxatilis (Teleostei). Biol. Reprod. 61, 1608 (1999).

33. Manning, A. J., Burton, M. P. M. \& Crim, L. W. The timing of puberty in cultured female yellowtail flounder, Limanda ferruginea (Storer): Oogenesis and sex steroid production in vivo and in vitro. Aquaculture 279, 188-196 (2008).

34. Felip, A., Zanuy, S., Muriach, B., Cerdá-Reverter, J. M. \& Carrillo, M. Reduction of sexual maturation in male Dicentrarchus labrax by continuous light both before and during gametogenesis. Aquaculture 275, 347-355 (2008).

35. Magliulo-Cepriano, L., Schreibman, M. P. \& Blüm, V. Distribution of variant forms of immunoreactive gonadotropin-releasing hormone and $\beta$-gonadotropins I and II in the platyfish, Xiphophorus maculatus, from birth to sexual maturity. Gen. Comp. Endocrinol. 94, 135-150 (1994).

36. Prat, F., Sumpter, J. P. \& Tyler, C. R. Validation of radioimmunoassays for two salmon gonadotropins (GTH I and GTH II) and their plasma concentrations throughout the reproductivecycle in male and female rainbow trout (Oncorhynchus mykiss). Biol. Reprod. 54, 1375 (1996).

37. Berkovich, N. et al. The intra-pituitary relationship of follicle stimulating hormone and luteinizing hormone during pubertal development in Atlantic bluefin tuna (Thunnus thynnus). Gen. Comp. Endocrinol. 194, 10-23 (2013).

38. Wańkowska, M. \& Polkowska, J. The pituitary endocrine mechanisms involved in mammalian maturation: maternal and photoperiodic influences. Reprod. Biol. 10, 3-18 (2010).

39. Rifkind, A. B., Kulin, H. E. \& Ross, G. T. Follicle-stimulating hormone (FSH) and luteinizing hormone $(\mathrm{LH})$ in the urine of prepubertal children. J. Clin. Invest. 46, 1925 (1967).

40. Schulz, R. W. et al. Spermatogenesis in fish. Gen. Comp. Endocrinol. 165, 390-411 (2010).

41. Rooker, J. R. et al. Life history and stock structure of Atlantic bluefin tuna (Thunnus thynnus). Rev. Fish. Sci. 15, 265-310 (2007).

42. Galuardi, B. \& Lutcavage, M. Dispersal routes and habitat utilization of juvenile Atlantic bluefin tuna, Thunnus thynnus, tracked with mini PSAT and archival tags. PLoS ONE 7, e37829 (2012).

43. Gomez, J. M. et al. Growth hormone $(\mathrm{GH})$ and gonadotropin subunit gene expression and pituitary and plasma changes during spermatogenesis and oogenesis in rainbow trout (Oncorhynchus mykiss). Gen. Comp. Endocrinol. 113, 413-428 (1999).

44. Molés, G., Gómez, A., Carrillo, M. \& Zanuy, S. Development of a homologous enzyme-linked immunosorbent assay for European sea bass FSH. Reproductive cycle plasma levels in both sexes and in yearling precocious and non-precocious males. Gen. Comp. Endocrinol. 176, 70-78 (2012).

45. Hassin, S., Gothilf, Y., Blaise, O. \& Zohar, Y. Gonadotropin-I and-II subunit gene expression of male striped bass (Morone saxatilis) after gonadotropin-releasing hormone analogue injection: quantitation using an optimized ribonuclease protection assay. Biol. Reprod. 58, 1233 (1998).

46. Holland, M. C. et al. Levels of the native forms of GnRH in the pituitary of the gilthead seabream, Sparus aurata, at several characteristic stages of the gonada cycle. Gen. Comp. Endocrinol. 112, 394-405 (1998).

47. Chapman, E. W., Jørgensen, C. \& Lutcavage, M. E. Atlantic bluefin tuna (Thunnus thynnus): a state-dependent energy allocation model for growth, maturation, and reproductive investment. Can. J. Fish. Aquat. Sci. 68, 1934-1951 (2011).

48. Rideout, R., Rose, G. A. \& Burton, M. P. M. Skipped spawning in female iteroparous fishes. Fish Fish. 6, 50-72 (2005).

49. Jørgensen, C. \& Fiksen, Ø. State-dependent energy allocation in cod (Gadus morhua). Can. J. Fish. Aquat. Sci. 63, 186-199 (2006).

50. Fleming, I. A. Reproductive strategies of Atlantic salmon: ecology and evolution. Rev. Fish Biol. Fish. 6, 379-416 (1996).

51. Sigler, W. F., Vigg, S. \& Bres, M. Life history of the cui-ui, Chasmistes cujus Cope, in Pyramid Lake, Nevada: a review. West. North Am. Nat. 45, 571-603 (2010).

52. Sawada, Y. et al. Testes maturation of reared Pacific bluefin tuna Thunnus orientalis at two-plus years old. Fish. Sci. 73, 1070-1077 (2007).

53. Holland, M. C., Hassin, S. \& Zohar, Y. Seasonal fluctuations in pituitary levels of the three forms of gonadotropin-releasing hormone in striped bass, Morone 
saxatilis (Teleostei), during juvenile and pubertal development. J. Endocrinol. 169, 527-38 (2001).

54. Jørgensen, C., Ernande, B., Fiksen, Ø. \& Dieckmann, U. The logic of skipped spawning in fish. Can. J. Fish. Aquat. Sci. 63, 200-211 (2006).

55. Logan, J. M. et al. Diet of young Atlantic bluefin tuna (Thunnus thynnus) in eastern and western Atlantic foraging grounds. Mar. Biol. 158, 73-85 (2011).

56. Knapp, J. M., Aranda, G., Medina, A. \& Lutcavage, M. Comparative assessment of the reproductive status of female Atlantic bluefin tuna from the Gulf of Mexico and the Mediterranean Sea. PloS One 9, e98233 (2014).

57. Parrack, M. L. \& Phares, P. L. Aspects of the growth of Atlantic bluefin tuna determined from marked-recaptured data. Collect. Vol. Sci. Pap. ICCAT 8, 356-366 (1979).

58. Abascal, F. J., Megina, C. \& Medina, A. Testicular development in migrant and spawning bluefin tuna (Thunnus thynnus (L.)) from the eastern Atlantic and Mediterranean. Fish. Bull. NOAA 102, 407-417 (2004).

59. Mañanós, E. L., Swanson, P., Stubblefield, J. \& Zohar, Y. Purification of gonadotropin II from a teleost fish, the hybrid striped bass, and development of a specific enzyme-linked immunosorbent assay. Gen. Comp. Endocrinol. 108, 209-22 (1997)

60. Wessel, P., Smith, W. H. F., Scharroo, R., Luis, J. F. \& Wobbe, F. Generic mapping tools: Improved version released. EOS Trans. AGU. 94, 409-410 (2013).

\section{Acknowledgments}

We thank Captains David Linney, Jim Ansara, Collin McKenzie, Joel Jacquard and Eric Jacquard for their assistance with sampling the fish. Dr. Iris Meiri-Ashkenazi and Vered Zlatnikov graciously assisted with the laboratory work. We acknowledge the late Peter C.
Wilson and Capt. Frank Cyganowski for initiating this research. Ben Galuardi contributed valuable comments to the manuscript. This work was supported by NOAA grant NA04NMF4550391 to M. Lutcavage.

\section{Author contributions}

G.H., M.E.L. Design of research and experiments, wrote the manuscript. G.H. fish sampling, endocrine analyses, data analyses. J.M.K. histology work. H.R. design of experiments, endocrine analyses. H.G. Design of research. All authors discussed and commented on the content of the paper.

\section{Additional information}

Supplementary information accompanies this paper at http://www.nature.com/ scientificreports

Competing financial interests: The authors declare no competing financial interests.

How to cite this article: Heinisch, G., Rosenfeld, H., Knapp, J.M., Gordin, H. \& Lutcavage, M.E. Sexual maturity in western Atlantic bluefin tuna. Sci. Rep. 4, 7205; DOI:10.1038/ srep07205 (2014)

This work is licensed under a Creative Commons Attribution-NonCommercialNoDerivs 4.0 International License. The images or other third party material in this article are included in the article's Creative Commons license, unless indicated otherwise in the credit line; if the material is not included under the Creative Commons license, users will need to obtain permission from the license holder in order to reproduce the material. To view a copy of this license, visit http:// creativecommons.org/licenses/by-nc-nd/4.0/ 